\title{
Political communications of the UK government as an institutional system
}

\author{
Larisa Bilalova ${ }^{1, *}$, Mikhail Guryev ${ }^{1}$, Oksana Ivanova $^{2,3}$, Olesya Ulybina ${ }^{1}$, Uliana \\ Khakhalkina $^{1}$ \\ ${ }^{1}$ FSBEI of HE Bashkir State University, Birsk, Russia \\ ${ }^{2}$ FSBEI HE Bashkir State Medical University, Ufa, Russia \\ ${ }^{3}$ FSBEI of HE Bashkir State Pedagogical University, Ufa, Russia
}

\begin{abstract}
The civilization process of social development as of the period of XX-XXI centuries caused the comprehensive development of man in the cultural and political science fields. The intensive growth of humanitarian, natural science and technical and technological knowledge has shaped the sociocultural and political activity of the population. In these conditions, political communication as a simplified version of "power-society" relationship is transformed into a separate area of human activity, which has a serious impact on personal identity. In modern conditions, political communication is not just a process aimed at transmitting any information. This is a multitude of processes where power should be considered as the source. There is a variety of processes represented in species diversity. Political communications in modern conditions have acquired the status of a social institution with its structure, internal systemic links and links with scientific knowledge, which play an important role in determining the vector of development of society.
\end{abstract}

\section{Introduction}

The article attempts to present the institutional status of the phenomenon of political communications as a structure of three main components. Firstly, the state as a governing body, represented by three branches of government: legislative, executive and judicial. Secondly, a society that acts as an addressee of state-power initiatives, which, due to its heterogeneous structure, either has a positive attitude to state policy, or negatively and puts forward opposition, or takes a wait and see attitude. At the same time, there are groups in society that are inclined to actively intervene in politics, such as, for example, political parties and which, expressing "feedback", are active participants in political communications. The third element of the political communications system is the media.

The authors proceed from the judgment that Great Britain is a classic, historically verified model of interaction between public authority and society. The study of the British experience of political communications is of interest from the point of view of the formation of a systematic diversity of social ties in the modern world.

\footnotetext{
*Corresponding author: philosofiya@mail.ru
} 
Purpose of the study. The purpose of this study is to characterize the political communications system of Great Britain as a socio-political phenomenon.

\section{Materials and methods}

In our opinion, the institutional approach will be methodologically correct for understanding political communications as a socio-political phenomenon. Such an angle of view allows us not only to reflect the entire multitude of diverse, diverse, species elements that make up the political communications system, their place and functional diversity, but also to reveal the specifics of the institutional system of political communications of the UK government.

Formulation of the problem. Before talking about the institutional system of political communications of the UK government, one should decide on the structure of the political communications institution in general. In its most general form, the specificity of political communication is to reflect a completely defined state (fragment) of the political process that characterizes the competitively localized interrelations between elite and non-elite groups (for example, relations during the period of legal formation of government bodies - elections). In this sense, this concept reveals the features of functionally interconnected actions of those who manages and being managed, taking into account their topological extent, spatio temporal localization, and positioning taking shape in real time. Consequently, on the basis of the corresponding theoretical model, it becomes possible to analyze the specific dispersal of power resources, to identify the nature and intensity of relationships in the "power population" system, to display the diversity and multi-directionality of information transmission channels. The presented conceptual construction makes it possible to display the specific content of functionally sequential (and at the same time spatially limited) information and communication processes in any territory. The communication space is not unlimited, it acts according to the parameters of the political system, since each political system has its own network of political communications and limited resources. The political system in communication theory is a technology that processes semi-finished products of public opinion and requests into political decisions. The technology here is the transfer of information from unofficial channels to official ones. The political system in this approach is identified with governance and is seen as a process of coordinating individual and group efforts to achieve certain political goals. The main mechanism by which this process manifests itself is not a function, as the proponents of structural functionalism believe, but the adoption and implementation of decisions. The political decisions made have certain consequences and are evaluated from the standpoint of values and authority.

The study of the issue. An analysis of the literature on the issues of the modern political and communicative process in general and the British, in particular, shows that the problems of research are multifaceted. The works of sociologists T. Parsons [16], K. Manheim [15], M. Weber [7] contributed to the formation of a modern understanding of political communications as a process of social interaction between managers and governed.

The problem of analysis and the essence of political communication was developed by G. Lasswell [1], J.-M. Kotre [24], L. Pay [26], M.N. Grachev [11,12], A.I. Soloviev [31], V. M. Berezin [2], and others.

So, the thoughts of J. Blondel are devoted to political leadership and the high degree of its influence on society, especially in national states [3].

Fundamentally important is the position of Daniel Lerner, who wrote in the middle of the 20th century about the interaction of political consciousness and the modernization of all spheres of social life: “... urbanization, industrialization, secularization, democratization, education, the role of the media do not appear randomly and not without communication with a friend. "[25] In turn, the works of S. Huntington are useful for our study in that he examines in detail the processes of modernizing the institutions of political power in Great Britain. S. 
Huntington, in particular, notes that England at the same time as the USA and Northern Europe came to the "diversification" of power, that is, to separation into independent power institutions, chronologically referring the reader to the time of bourgeois transformations in these countries [21].

Political communications as a way to establish socio-political relationships were studied by Russian scientists L.A. Agaronyan [1], S.V. Paulov [17].

J.-F. Lyotard wrote about the importance of information technology in political strategies [14]. The importance of the information space for the development of the institute of political communications was studied by such foreign scientists as D. Bell [23], E. Toffler [20], M. Castells [11]. Among the Russian scientists developing this problem can be called Yu.P. Budantseva [6]. Of interest to our study is the book of Ground Wars Personalized Communication in Political Campaigns, a researcher at the Reuters Institute for the Study of Journalism at Oxford University, Rasmus Clays Nielsen, where he, based on modern empirical material, shows the crucial role of the media in political campaigns. [27] However, research in this area is clearly not enough, especially since they do not fully reflect government communications in the information and public sphere of a particular country the UK.

An analysis of the concepts that interpret the phenomenon of political communications shows that most researchers of political and communication processes, including political science courses, use the term "political communication" in the singular, implying an integral multi-level and multi-aspect structure. It is rather difficult to distinguish from the mass of scientific discrepancies of the phenomenon of political communications an essential wording reflecting the totality of the components of the studied social phenomenon.

When acquainting ourselves with works representing thoughts on the issue of political communications, we drew attention to the linguistic aspect of the problem: more often the term is used in the singular (political communication), while some authors use it in the plural (political communications). In the aspect of the essential approach, this is not just a pretentious look at the subject of research, but the ability to most fully cover all aspects of the phenomenon of political communications as an institutional system.

In the text of the textbook "Modern Political Communication" edited by A.P. We find Chudinova: "Political communication is a process of communication between participants in political activity. The term communication goes back to the Latin communico, which means I make common, connect, communicate. Modern experts call communication a joint activity in coding, transmission and perception of information. Two parties participate in communication: the addressee (speaker or writer) and the addressee (listener or reader) "[18]. In this case, we consider political communication as a phenomenon - communication between the government (addressee) and the people (addressee). In other words, political communication in this perspective appears as the information impact of the government (state) on the population for management purposes. This givenness (communication) is objectively and immanently inherent in human society. In early societies, the process of political communication was quite simple: power governs, people are governed. The civilization process of social development as of the period of XX-XXI centuries caused the comprehensive development of man in the cultural and political science fields. The intensive growth of humanitarian, natural science and technical and technological knowledge has shaped the sociocultural and political activity of the population. In these conditions, political communication as a simplified version of the relationship "power-society" is transformed into a separate area of human activity. The term political communications is actualized in the plural precisely by virtue of the principle of an essential approach to the subject of research. In modern conditions, political communication is not just a process aimed at transmitting any information. This is a multitude of processes where power should be considered the source. This is a variety of processes represented in species diversity. Political communications in 
modern conditions have acquired the status of a social institution with its structure, internal systemic links and links with scientific knowledge, which play an important role in determining the vector of development of society.

\section{Results}

We will try to structurally present the institutional status of the phenomenon of political communications.

Firstly, the state participates in political communications as a governing body, represented by three branches of government: legislative, executive and judicial. In the structure of political communications, we give him priority place, since we consider it as a source of state-power activity, an ideologist (laws, orders, etc.).

Secondly, in the structure of political communications, we include a society that acts as an addressee of state - power initiatives. Being heterogeneous in its structure, society either has a positive attitude to public policy, or a negative attitude and puts forward opposition, or takes a wait and see attitude. At the same time, there are groups in society that are inclined to actively intervene in politics, such as, for example, political parties and which, expressing "feedback", are active participants in political communications.

The third element of the political communications system is the media. According to the content of information issued by the media in the aspect of socio-political relations, they can be schematically divided into pro-state, opposition and the so-called "yellow press", which can play on both fields, depending on the customer. In the case of Great Britain, it will be schematic as follows (Figure 1): 


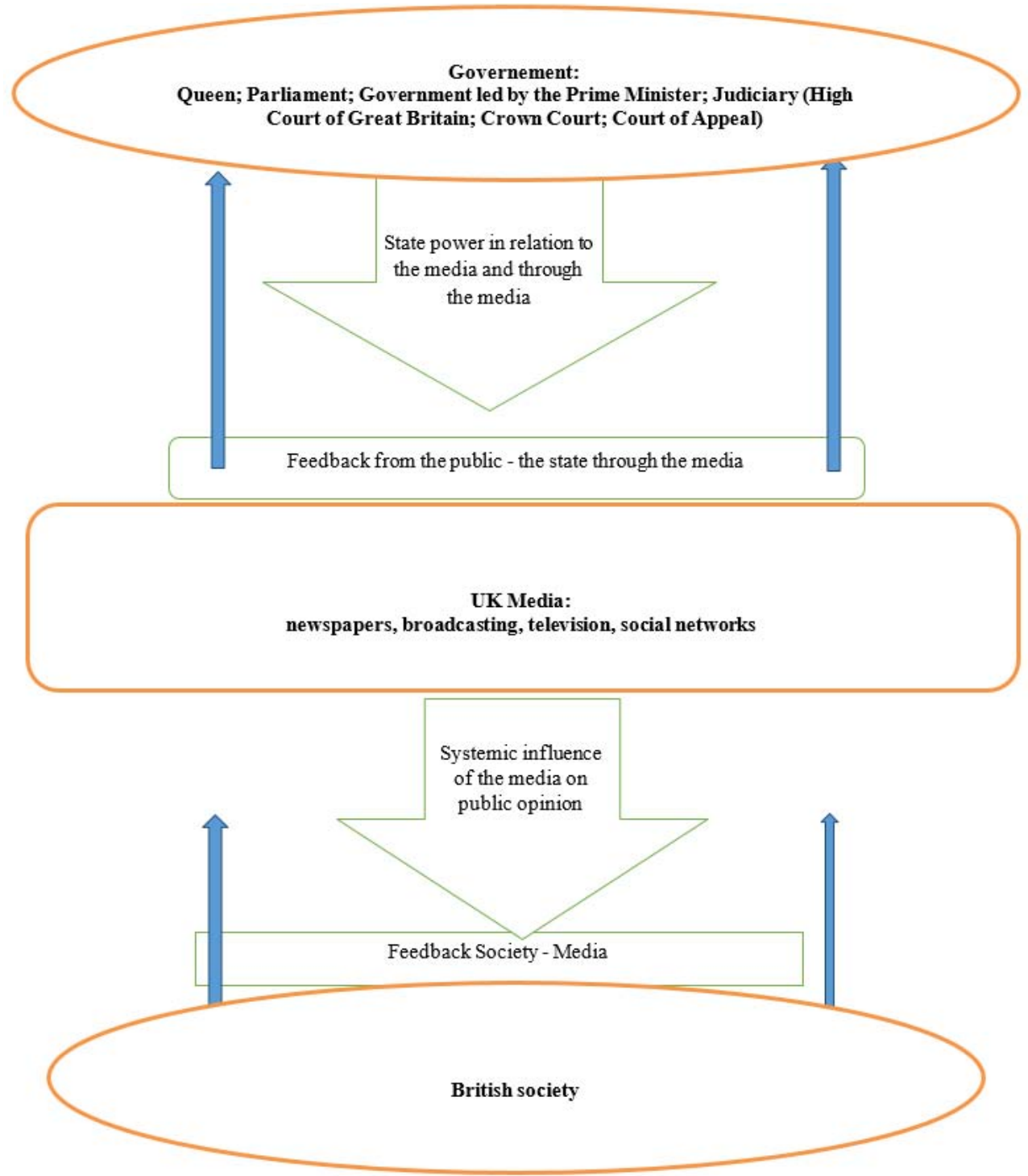

Fig. 1. Diagram In the case of Great Britain.

The diagram clearly shows that the UK government authorities are actively communicating with the country's media in order to influence and manage society. Political attitudes are transmitted through the media from UK government to society, shaping, leveling public opinion. As feedback through the same British media, the state receives information about the British mindset, about attitudes towards certain government projects, programs, initiatives, etc. The presented scheme can characterize the system of socio-cultural communications of any modern society.

The power of the printed word at the beginning of the 20th century was justified by V.I. Lenin. We think that it will be appropriate to give an excerpt from his work here: "we certainly need a political newspaper. Without a political organ is unthinkable ... a movement deserving of the name political. Without it, our task is absolutely impossible - to concentrate all the elements of political discontent and protest. 
The role of the newspaper is not limited, however, to one dissemination of ideas, one political education and the involvement of political allies. A newspaper is not only a collective propagandist and collective agitator, but also a collective organizer ... With the help of the newspaper and in connection with it, a permanent organization will be formed, busy ... with regular joint work, accustoming its members to closely monitor political events, to evaluate their significance and their impact on different segments of the population, to develop appropriate ways to influence these events..." [13].

As we know from Russian experience, the printed word managed to organize the population of a huge country into decisive and fundamental changes in the political system. Modern media represent a more powerful social force than it was in the recent historical past. The diversification of the media into print media (newspapers, magazines), radio, television, the Internet, admittedly, has turned them into the so-called "fourth power" in terms of their impact on society and the state. Being a part of public life formed by a social institution, the media not only reflects public opinion, but also shapes it, including in the field of state power, in political circles. In conditions of wide literacy and social activity of the population of the countries of the world, information transmitted by the media is quickly disseminated in society, having a strong impact on the communicants.

As political and communicative forms of interaction between the state and society in modern society, such as referenda, polls, and election campaigns have become widespread.

All the structural elements of political communications that we have mentioned above together constitute a socio-political and historical-cultural institution that has some specifics in individual countries.

Let us turn to the sketch of the institutional system of political communications of the UK government.

The institutional system of political communications in modern Britain is a combination of interactions between state, party, socio-political institutions. All of them, to one degree or another, express and represent the interests of various segments of society, from socially significant group to private. The leading instrument for the realization of public interests is the state. By maximally concentrating power and resources in their hands, the state distributes values and encourages the population to compulsory implementation of their decisions.

Modern English society as a structural unit of the system of political, in particular, and intercultural communications in general, according to the materials of the BBC Russian service since 2013, the source has been divided into seven different classes (instead of three, as it was in the 20th century). The basis for dividing the population into classes has become the parameters that are most relevant, in our opinion, reflecting the realities of modern life in general: economic (income, savings, real estate), social (connections and social circle) and cultural (interests and ways of spending time). "The seven social varieties are included in the new model of social classes - from the elite to the so-called" precariate "(the most socially vulnerable segment of the population that does not have stable sources of income and social guarantees)" [4]. Despite the changes in the social-class structure of modern Britain, it should be noted that in the aspect of vertical social mobility, English society remains very conservative. This is confirmed by the results of research by the BBC service, which analyzed a number of evidence and cited an extract from the report of the Organization for Economic Co-operation for 2010: “... Great Britain really occupies one of the last places in terms of some social mobility: for example, the prospects for a child getting higher education and paying well are largely determined by the property status of his parents "[5]. The relatively low social mobility of the population of England, in our opinion, characterizes the specifics of its intro-social communications.

One of the key elements of the institutional structure of political communications of the UK government is the media. It is they who serve as a link between state power and society in the dissemination of information, the formation of public opinion. For example, television 
"is considered part of the national culture, and no one is ashamed of it." [22] According to O.P. Ilysheva "at the beginning of the 20th century, Great Britain formed one of the most developed mass media systems at that time. At the beginning of 1922, regular broadcasting began in the country, in the second half of 1936 the BBC Corporation launched the first broadcasting in the world for the first time in the world, and in December of the same year it conducted the first live broadcast of world history from the coronation ceremony of George VI. The Second World War slowed down, but did not stop the development of the British media. And after its completion, official London had at its disposal one of the most technologically advanced television and radio broadcasting systems, as well as many influential and authoritative print publications, in particular, 1,441 newspapers were published in Britain in 1948 "[10].

\section{Discussion}

As the vast majority of British scholars note, by the end of the twentieth century, the influence of mass media on the very structure of the establishment and its relationship with the rest of society has become key. Let us single out several channels of the indicated influence:

1) Currently, the media establishment has entered the British establishment. These are popular presenters of television news, editors of major national newspapers, members of the professional community of political journalists - the Lobby, or the Commonwealth of Journalists of the Parliament Hall, the first parliamentary-government pool in history. Although it has existed in British journalism since 1884, it was only in the 21 st century that it began to be perceived as part of an influential layer.

Owners of media concerns should also be included in this category, although their influence on public consciousness is not direct, but is mediated by the media themselves and political figures with whom media tycoons are affiliated in order to prevent the adoption of antitrust laws in the media sphere. The story of BAP, the British-American Project born in the bowels of the White House in the early 1980s, speaks more about the level of influence of the media person within the establishment more eloquently than others.

2) A new way has been formed for recruiting the elite: through the media. It was the press and television that created within the establishment a new group - media celebrities, or celebs ("celebrities"). The establishment included not only parts of the political and economic elite along with journalists, but also sports stars, show business, mass culture and "ordinary people" turning into celebrities due to extraordinary (sensational) events in their lives;

3) There was a redistribution of influence within the establishment depending on the interest of the media. One vivid example is Princess Diana, whose participation in the events was more authoritative and influential and attracted much more attention than the participation of her husband. The same can be said about the House of Commons, where active backbenchers (parliamentarians from the back benches, that is, not holding important posts) can today receive more attention and are more often quoted than even the Shadow Cabinet; - Some elite groups left the establishment: scientists, military, judges.

Today, their influence on public opinion can be called twice indirect - through the influence on the establishment and the subsequent influence of the establishment on the media;

4) The formation and entry into the establishment of media figures (media persons with mediated personalities) - for example, leaders of public organizations and trade unions, which in the minds of the layman "detach" from their organizations and begin to function as independent information figures;

5) The new quality of the establishment has become dominant - its media, that is, dependence on the media and constant adaptation to their needs. As we shall see, this is the whole work of the establishment with public information. 
Thus, at the end of the twentieth century, the life and preservation of leadership positions for the British establishment depended largely on access to (and control over) the media, and through them, on the management of public opinion.

Taking into account the new qualities of the British establishment in the last quarter of the twentieth century, we note that it consists of the following significant strata:

- active political establishment: king / queen, leaders of parties (including regional) and parliamentary factions, party activists in parliament and localities, members of the British Parliament and regional assemblies (especially heads of parliamentary commissions and committees), members of the government, mayors of major cities, union leaders, families and advisers to political leaders. The political establishment, by virtue of real power and the overall image of the "leader of the nation" imposed on it, personifies the establishment as a whole and has the greatest resource of pressure on the communication space;

- economic establishment: owners and top management of large businesses (both British and foreign residents with interests in the country's economy), financial analysts, financial information consultants, prominent economic journalists and owners of the financial press;

- media elite: media owners, leading journalists, editors of national and large regional media, the journalistic lobby;

- celebrities from the world of sports, show business, science, culture, the royal family and the media-covered part of the class aristocracy, as well as ordinary citizens who are currently in the focus of media coverage. As already mentioned, the survival of the establishment in its established form and composition critically depends on the state of public consciousness and public opinion about it. Under these conditions, communication based on proactivity and a strategic approach to it becomes a key factor for the survival of the establishment.

Great Britain is characterized by publicly declared commitment to democratic concepts of human freedom, equality, openness and civic participation, publicity and transparency of political competition, the desire for innovation in public administration and political life in general. This leaves an imprint on the government's public strategy regarding political communications.

At the same time, the British authorities cannot refuse extensive control and vertical communication with society. Nevertheless, objective reality makes fiscal policy more restrained, often masking the true component of its actions. For example, vertical mass political communication is presented as horizontal, "from peer to peer," the highest degree of control over society is hidden under the principles of "universal openness", political discourse is limited to transparent frames. A typical illustration of our thesis is the situation with the refusal of the Dukes of Sussex to fulfill royal duties. Through the media, the world community was informed about the royal family's agreement with the decision of the younger members of the family. The verified restraint of the Queen's text is aimed at preserving the dignity of the monarchy as the mental stronghold of British society and its stability.

In general, communication in the field of activity of the UK government, like any communication acts, pursues three goals: the transfer of information, a change of opinion, a change in the behavior of the informants. However, the key to this process is undoubtedly a change in behavior, since it is this that forms the core of power - management relations in the UK society.

Accordingly, the use of the media and control over the content of their messages is one of the prerequisites for the exercise and retention of power in the UK information society. It is important to note that the essential side of the political and communication processes identified in the activities of the UK government is the transfer, movement and circulation of political information, in fact, as well as political communication in general. The British 
establishment primarily uses the totality of information in the hands of the government, taking into account internal and external factors.

\section{Conclusion}

Speaking about the institutional status of political communications of the UK government and its role in the system of intercultural social ties, the following conclusions should be made:

1) The Institute for Political Communications of the Government of Great Britain consists of classical elements, namely: the state-power elite, which actively uses the media in their combined diversity in promoting political ideas. Institutional status is proved by the systemic interconnectedness and interdependence of the structural elements that make up political communication.

2) The British establishment in the post-modern era is a collection of representatives of not only the aristocratic elite, elected representatives of the regions, but also prominent figures of the media, which, of course, significantly reduces the status of media independence.

3) In the process of building political communications in Great Britain, the institution of the monarchy plays a prominent role, supported by the conservative worldview of most Britons. The principle of the ascriptiveness of royal power actually means the formality of royal power. At the same time, in the institutional status of political communications, the British monarchy plays the role of a stabilizer of public sentiment.

4) The relatively low social mobility of the population of England, in our opinion, characterizes such a feature of intro-social interactions between society and the state as adherence to traditions, which largely determines the cultural status of British society in the global space.

5) The media in the UK's political communications system reflect typical attitudes of the population, representing a system of pro-state, opposition, and neutral-expectant information blocks.

\section{Acknowledgments}

The authors of the article thank the Doctor of Philosophy, Professor Yuri Nikolayevich Dorozhkin, who acted as the scientific consultant of the topic.

\section{References}

1. G. Lasswell, Analytical portal humanitarian technologies https://doi.org/10.1086/266081

2. M. Castels, Binding force (Oxford University Press, 2011) https://www.researchgate.net/publication/317574829_Book_Review_Castells_Mauel 2009_Communication_Power_Oxford_University_Press_ISBN_-_9778-0-19-956704-1

3. A.I. Solov'ev, Polis 3, 12 (2010) DOI: 10.17976 / jpps / 2002.03 .02

4. V.V. Pshinskaya, Sociodynamics 5, 80-92 (2014) DOI: 10.7256/23060158.2014.5.12145

5. V.V. Komleva, Central Russian journal of social Sciences (2015) DOI: 10.12737 / 16786

6. A.V. Nazarchuk, Political research 3, 136-149 https://doi.org/10.17976/jpps/2006.03.11 
7. S.A. Druzhilov, Hygiene and sanitation (2018) DOI: http://dx.doi.org/10.18821/00169900-2018-97-7-597-603

8. V.V. Karpov, Politics and society, 611-625 (2016) DOI: 10.7256/18128696.2016.5.13326

9. O.Yu. Tsendrovsky, Genesis: historical research 5, 279-337 (2015) DOI: 10.7256 / 2409-868X. 2015. 5. 16301

10. A. Toffler, H. Toffler, Revolutionary Wealth (Knopf, 2013) https://sites.google.com/site/dropexelat/revolutionary-wealth-76782028

11. R. Nielsen, Ground wars: personalized communication in political campaigns (Princeton University Press, Princeton, Oxford, 2012) doi:10.2307 / j. ctt7rs6w

12. M. McCombs, R. Holbert, S. Kiousis, W. Wanta, News and public opinion: the influence of mass media on civil life (Polity Press, Cambridge, England, 2011) https://pdfs.semanticscholar.org/828e/c6331eeb745bbac06ddba8f4caff85910a58.pdf

13. B. Williams, Lenin (Routledge, Abingdon, Oxon, 2014) https://www.bookdepository.com/Lenin-Beryl-Williams/9780582437609

14. D. Robson, How Important is Social Class in Britain today? (Bbc.Com, 2016) https://www.bbc.com/future/article/20160406-how-much-does-social-class-matter-inbritain-today

15. K. Voltmer, Mass Media And New Democracies (Routledge, 2012) https://reutersinstitute.politics.ox.ac.uk/sites/default/files/201711/Media\%20and\%20Democratisation.pdf

16. E.V. Rubtsova, N.V. Devdariani, Baltic humanitarian journal (2019) DOI: 10.26140/bgz3-2019-0804-0067

17. G. Wolfsfeld, Understanding media and politics: five principles of political communication (Routledge, New York, 2011) DOI: 10.1080/10584609.2012.697029 